\title{
Commercial Production and Chemical/Physical Characterization of Natural and Nutritious Coconut Sap Food Products (Cocosap Juice and Cocosap Concentrate) at Tawan-tawan, Baguio District, Davao City, Southern Mindanao, Philippines
}

\author{
Millicent I. Secretaria ${ }^{1}$ and Timoteo A. Adon, Sr. $^{2}$
}

\begin{abstract}
The processing of natural and nutritious coconut sap juice and coconut sap concentrate for commercial production was conducted by the members of the Samahang Magniniyugan ng Tawantawan (SMT) at Barangay Tawan-tawan, Baguio District, Davao City, Southern Mindanao, Philippines from February to May, 2007. The processing of coconut sap juice and concentrate involves simple, easy to follow procedures and few equipment are required.

Results of the chemical analysis revealed that coconut sap juice, an oyster-white liquid and coconut sap concentrate, a sticky, golden orange syrup has $84.3 \%$ and $25 \%$ moisture content; $0.24 \%$ and $0.94 \%$ crude protein; 18.99 and $63.79 \mathrm{mg} / 100 \mathrm{mg}$ sodium $(\mathrm{Na}) ; 0.85$ and $1.51 \mathrm{mg} / 100 \mathrm{~g}$ calcium (Ca) and 0.05 and $0.33 \mathrm{mg} / 100 \mathrm{~g}$ iron $(\mathrm{Fe})$, respectively indicating that these coconut sap food products are nutritious and good for one's body. While physical (color) analysis showed that these products are pure and natural since no food coloring was detected. A partial budgeting analysis on the profitability of producing coconut sap juice and coconut sap concentrate over the traditional fermented toddy indicated an additional profit or net income of Php19,728.00 and Php21,402.00 per month, respectively $(\mathrm{Php} 41=\$)$.

The benefits derived from the commercialization of the technology on coconut sap food products by the adaptors were discussed. Factors for successful adoption and commercialization of coconut sap juice and concentrate were likewise recommended.
\end{abstract}

Keywords: Coconut sap concentrate, coconut sap juice, chemical, physical characterization, technology commercialization.

\footnotetext{
${ }^{1}$ Science Research Specialist II \& Scientist 1, Philippine Coconut Authority-Davao Research Center (PCA-DRC), Bago Oshiro, Davao City, Philippines.

E-mail address: pcaasd@pldtdsl.net or milsecretaria@ yahoo.com

${ }^{2}$ Chairman, Samahang Magniniyugan ng Tawan-tawan, Barangay Tawan-tawan, Baguio District, Davao City, Southern Mindanao, Philippines.
} 


\section{Introduction}

The coconut as a "TREE OF LIFE" is characteristically a food supplier as this tree provides fruit throughout the year. Its fruit is edible at any stage of maturity, main source of many food products (coco milk, oil, chip, copra, nata de coco, and many others), its water is a healthy drink/ beverage while its unopened inflorescence can produce coconut sap which can be processed into natural and nutritious food products.

Coconut sap or toddy, the natural and quite sweet exudate from the tapped unopened inflorescence (spathe) of coconut, is one of the best food products to consider because of its many food uses. It could be marketed as an alcoholic drink (4-6\% alcohol) locally known as 'tuba' or coconut wine; as vinegar (under further natural fermentation) or as 'lambanog' or distilled wine $-24-45 \%$ alcohol (Fig. 1). The sap can also be processed into coconut sap juice/drink, syrup or concentrate, crude sugar or granulated brown sugar and vinegar. The process involved simple and easy to follow procedures and few equipment are required. In the Philippines, the technology on the production of coconut sap food products was developed by the technical staff of Agronomy and Soils Division in 2001 at PCAZamboanga Research Center, San Ramon, Zamboanga City (Secretaria et al. 2003).

The technology was first adopted for the commercial production of coconut sap sugar in 2002 by the Linabu Small Coconut Planters Association (LSCPA), Balingasag, Misamis Oriental, Northern Philippines with an initial production of one (1) $\mathrm{kg} /$ day at P60/ $\mathrm{kg}$ (Cruz et al. 2006). In 2003, there was increase in coconut sap sugar technology adoption and commercialization with Barangay Waterfalls, Balingasag, Misamis Oriental pursuing the same technology. Last year (2006), eleven (11) farming families of the LSCPA are producing coconut sap sugar with potential production of three (3) tons. On the other hand, coconut vinegar from coconut sap has been produced commercially due to its easy procedure i.e. natural fermentation of coconut sap. One notable food enterprise that is now exporting cocosap vinegar in USA, Singapore and Malaysia not to mention its local market in the country is the Sorsogon Foods Enterprises (SFE) with vinegar brand "Lola Conching" and its coconut plantation based in Barangay San Rafael, Fabrica Bulan, Sorsogon, Bicol Region, Philippines.

Recently, the technology on the production of coconut sap food products was presented in a Mindanao-wide Technology Commercialization Forum sponsored by Department of AgricultureBureau of Agricultural Research (DA-BAR) last August 17, 2006 at Davao City. The technology was received by coconut stakeholders as a very potential business enterprise. Likewise, PCADRC/Regional Office XI have been promoting these food products in different provinces of Region XI (Southern Mindanao) due to their social, economic and nutritional benefits (Secretaria et al., 2006). The technology is technically feasible, socially acceptable and most of all, environment - friendly since food products come from abundant natural resources such as coconut palms.

The development of the technology on natural food products from coconut sap is very timely considering the growing consciousness of consumers on safe, natural and healthy food products. It also provides additional job opportunities among coco-based farming communities, where other members of the family particularly women can be involved in processing considering that the technology is simple and easy to apply. As a health food, coconut sap is a good source of vitamins, amino acids (Kosaki, 1974 cited by Magat, 1996), vitamins, carbohydrates, protein etc. (Naka, 1996), eight macronutrients and five micronutrients (Secretaria, 2003).

Figure 1. Coconut products derived from coconut se 
Hence, there is a need for technology piloting/validation particularly on coconut sap juice and concentrate commercial production, thus this project involved the commercial production of newly developed natural and nutritious coconut sap juice and concentrate in the village level by a registered small coconut farmers' organization.

\section{Objectives:}

a) To validate and showcase the technology on the production of coconut sap into coconut sap juice and concentrate through actual processing by a selected Small Coconut Farmers' Organization (SCFO);

b) To promote and transfer the coconut sap food production to a coconut farm community via technology training, information, education and communication (IEC) materials, on-farm provision of technical services on selected cases;

c) To characterize chemically and physically the coconut sap juice and concentrate produced by the selected SCFO; d) To assist in the product development and marketing of coconut sap food products or in the commercialization of high value coconut sap food products.

\section{Methodology}

a) Project Site - Barangay Tawan-tawan, Baguio District, Davao City, Philippines.

b) Experimental palms: Local coconut hybrid, Catigan green dwarf X Laguna tall (CATD x LAGT) palms planted at the coconut areas of the members of Samahang Magniniyugan ng Tawantawan (SMT) were used for the tapping of coconut sap. CATD x LAGT hybrid had been found to be one of the identified high yielding (coconut sap and nut producing) coconut hybrids and varieties in the country (Secretaria et al., 2002). About 50 trees or at least 0.50 ha of coconut palms were tapped for the production of coconut sap to be processed into cocosap juice and cocosap concentrate.

c) Project Implementer: Members of Samahang Magniniyugan ng Tawantawan (SMT), Barangay Tawan-tawan, Baguio District, Davao City, Philippines. 
At present, toddy tapping is one of the activities of coconut farmers in this locality as additional source of their farm income. The farmers sell their toddy as fermented toddy or 'tuba' to barrio folks.

d) Training of coconut farmers on the proper tapping procedure for coconut palms to obtain sweet coconut sap (toddy) as requirement for production of coconut sap juice and concentrate. The coconut farmers used the full tapping technique (sap production only) from coconut palms in contrast to the sequential coconut toddy and nut production (SCTNP) scheme developed by Maravilla and Magat (1993). The preparation of equipment and palms for toddy tapping, were done following the procedure of Secretaria, etal. (1997). While the tapping procedure used were as follows:

selecting younger but swollen spathe (unopened inflorescence) at the base which is next to the biggest closed spathe;

wrapping of the selected unopened spathe with plastic twine;

gradual bending downward of the spathe using a plastic twine to a petiole below so as not to break the stem;

- keep bending the spathe for seven (7) days until it droops;

- slicing the spathe daily with sharp knife, cut open the tip of the spathe when bending is half done until the sap regularly flows;

○ when the sap started to flow out, the spathe was wrapped with wetted dry banana leaves gathered in the morning and tie with young coconut leaflet to hold the wrappings;

○ the wounded end of the spathe was then inserted into the open end of the bamboo receptacle;
- the receptacle was fastened to the spathe and its mouth covered with coconut stipule ("guinit")

- the spathe was thinly sliced daily to allow the sap to flow continuously until the whole spathe was tapped. The drooping position of the spathe prevented the sap from flowing back to the inflorescence and to collect the sap into the bamboo receptacle.

Generally, when the coconut inflorescence is tapped, a very sweet juice exudes from it. It is called coconut toddy in Malaysia, Sri Lanka, Philippines and other countries (www.fao.org/inpho/content/text/ch15.htm). In Guam, coconut sap juice, freshly extracted from a young, healthy coconut tree is chilled and is absolutely delicious (http://www.anderson.af.mil/news/story).

Some necessary procedures for sweet sap production done by the SMT coconut farmers were as follows:

d1) Coconut sap was collected from 6:00 to 8:00 a.m. and again between 3:00 - 5:00 pm everyday, about $3 \mathrm{~mm}$ were trimmed off at every collection;

d2) The coconut sap, being highly perishable should be preserved immediately so as to prevent deterioration. The most important prevention of this deterioration is by keeping clean of all equipment used in tapping. The knife has to be sharp and clean.

In Thailand, farmers use special bark e.g. kiam (Cotyleobium lanceolatum) and prayom (Shorea floribunda) for preservation. In some places, mixtures of preservatives are used instead of kiam and pra-yom. The preservative is a mixture of sodium metabisulphite, sodium propionate, sodium benzoate in a ratio of 10:1:1, respectively (Naka, 1996). On the other hand, for this particular project, no 
preservative or additive was added to the cocosap to preserve the product.

d3) Cleanliness of the spathe by properly wrapping it with clean wetted banana leaves to prevent insect infestation; washing used tools thoroughly everyday and filtering of coconut sap from the bamboo to the plastic container using strainer with very fine alaskin cloth were done to ensure sweetness of the coconut sap;

d4) The materials and tools used by the tappers were tapping knife, collection vessel (bamboo receptacle), plastic twine, bamboo paddle, coconut stipule.

e) Training of the SMT members on the processing of coconut sap juice and cocosap concentrate technology. The procedure were as follows:

1) Coconut sap juice

1a) Filter coconut sap from the plastic container (from field using a plastic strainer to the cooking vessel;

1b) Pasteurize the coconut sap for 10-15 minutes for $65^{\circ} \mathrm{C}$ to prevent natural fermentation, monitoring of temperature was done by using a dial thermometer;

1c) Cool and pour pasteurized coconut sap in the desired container bottles;

1d) Seal tightly and place in the cool section of the refrigerator or freezer if the juice is to be transported to consumers in distant place;

1e) If hygienically prepared, the finished product can be stored until for seven (7) days (at cool section of the refrigerator) and at most one (1) month (at freezer) without deterioration.

\section{Coconut sap concentrate}

2a) Filter coconut sap using a plastic strainer from the plastic container to the cooking vessel;

2b) Boil coconut sap until it reaches $110^{\circ} \mathrm{C}$ temperature or coconut sap becomes sticky under moderate to very low heat. The color of cocosap changes from cloudy or oyster white to golden orange;

2c) Cool the golden orange, sticky cocosap concentrate, then pour into desired container;

2d) Store in room temperature (shelf life $=$ six (6) months) or in refrigerator to prolong shelf life (up to one year without deterioration).

e) Chemical and physical (color) analysis of coconut sap juice and concentrate were done by the Department of Science \& Technology (DOST) XI, Testing \& Calibration Center, Davao City and Bureau of Food and Drugs (BFAD), Satellite Laboratory, Tagum City, Davao del Norte, respectively.

f) Food Safety Seminar to the SMT members was conducted by the Food Safety Team of the DOST XI.

g) Technology product promotion/awareness thru lectures, dissemination of techno guide sheets, product exhibition in trade fairs.

h) Development of product labels for coconut sap juice and concentrate thru the assistance of the DOST XI artist

i) Marketing of coconut sap juice and concentrate to prospective buyers

\section{Results and discussion}

\section{Initial implementation of the project}

The project was initially implemented on February 9, 2007 with a meeting of the Project 
Leader with SMT Officers and members to give the details of the project i.e. objectives, methodology and expected output of the project (Fig. 2). On the same date, the signing of the Memorandum of Agreement for the implementation of the project was done between PCA-DRC represented by Ms. Millicent I. Secretaria, Scientist 1 and Project Proponent and the Samahang Magniniyugan ng Tawan-tawan (SMT) represented by Mr. Timoteo Adon, Sr., Chairman of the SMT (Fig. 3). This event was witnessed by Officers and members of the SMT.

On February 16, 2007, the SMT received the equipment such as refrigerator, supplies and materials i.e. plastic containers and kitchen materials from a government funding agency (Southern Mindanao Agriculture, Resources Research and Development Consortium) to be used in the project implementation. The equipment and supplies/materials were handed in to the SMT Chairman by the Project Proponent (Fig. 4).

Likewise, on the same date, the Project Leader provided training or actual demonstration on the processing of coconut sap juice and coconut sap concentrate. (Fig. 5). The finished products were taste tested by the members of the SMT and some children in the locality. (Fig. 6).

After the actual demonstration of processing of cocosap juice and concentrate, the womenprocessors of SMT started to produce these products. Initial processing of cocosap juice and concentrate was done
Figure 2. Proj. Proponent Ms. Millicent I. Secretaria briefed the SMT members/officers about the cocosap food products commercialization project to be conducted Barangay Tawan-tawan, Baguio District, Davao City on February 09, 2007. coconut sap juice produced during the initial stage were not sold but were provided to pupils of the Tawan-tawan Elementary School Tawantawan, Baguio District, Davao City and during meetings of the rural folks of the San Roque Parish parishioners. Most of the product produced was the coconut sap concentrate since the target clienteles for the coconut sap juice was not assured due to the closing of classes of the Tawan-tawan Elementary School. The total coconut sap concentrate produced by the SMT from Feb. 25 to April 11, 2007 was 283 bottles (@250 ml/bottle). The initial coconut sap concentrate produced were sold to interested people at the San Roque Cooperative Store, Tawan-tawan, Baguio Dist., Davao City, Davao City Medical Mission Hospital (DCMH), Sta. Ana Ave., Davao City (since one of the daughters of SMT Officer works at DCMH.

\section{Chemical and Physical Analysis of Coconut sap Juice and Concentrate}

Coconut sap, the raw material for coconut sap juice and coconut sap concentrate when freshly gathered is sweet, oyster-white and nearly neutral in $\mathrm{pH}$ (Magat, 1996). The physical and chemical composition of coconut sap is shown in Table 1. The sap is rich in amino acids, specifically glutamic acid (Table 2). Glutamic acid is an amino acid used by the body to build protein, it plays a role in the normal function of the prostate gland (http:www/vitacost.com/science/glutamic acid. html). It also contains lots of vitamins (Table 3), found to be

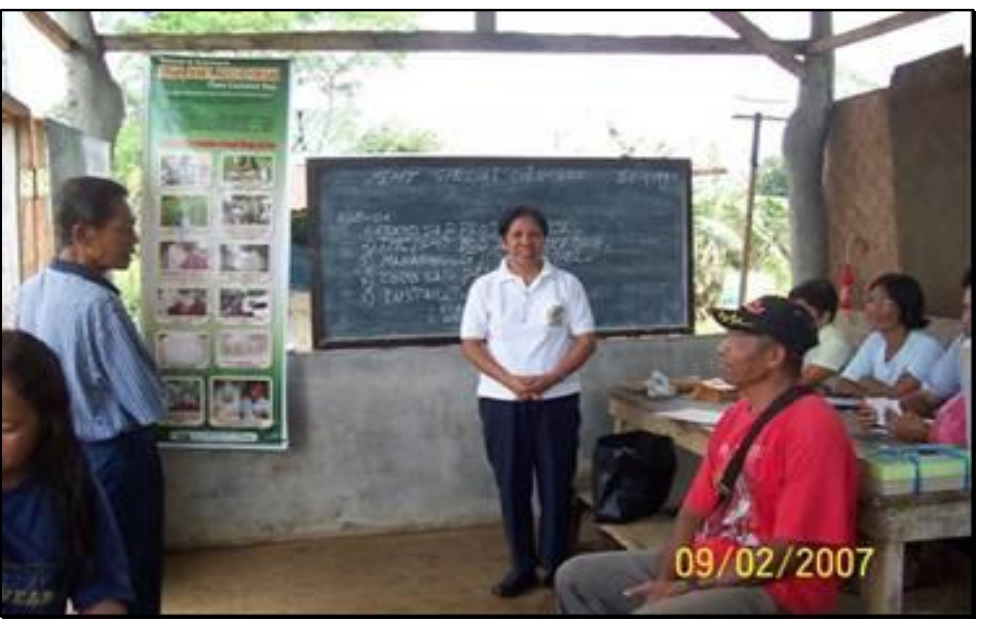


Figure 3. MOA signing by Ms. Secretaria (PCA-DRC) and Mr. Adon, Sr (SMT) for the implementation of coconut sap food products commercialization project.
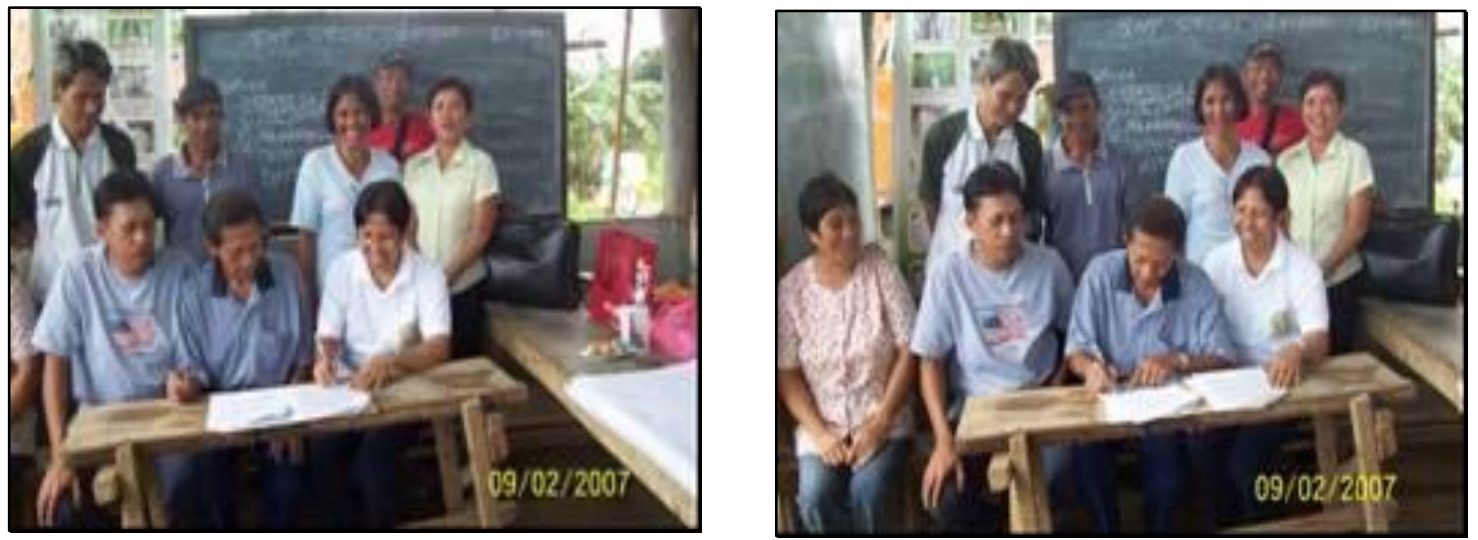

Figure 4. Ms. M. Secretaria handed the refrigerator and plastic containers to Mr. Adon, Sr. and kitchen materials to the women-members of the SMT to be used in the production of coconut sap juice and concentrate at Tawan-tawan, Baguio District, Davao City.

\begin{tabular}{|l|c|}
\hline $\begin{array}{l}\text { Table } \\
\text { of coco }\end{array}$ \\
\hline Parameter & $1.067-1.07$ \\
\hline Specific gravity & $17.40-18.70$ \\
Total solids (\%) & $14.80-16.60$ \\
Sucrose (\%) & trace -0.30 \\
Reducing sugars (\%) & trace -0.40 \\
Crude protein (\%) & $0.30-0.40$ \\
Ash (\%) & \\
\hline
\end{tabular}

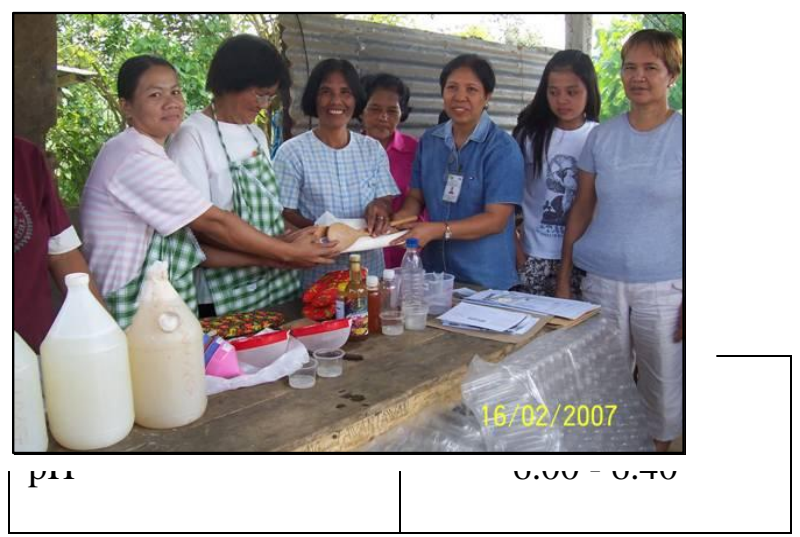

Table 2. Amino acid content of freshlygathered coco sap (Kozaki, 1974 in Magat, 1996)

\begin{tabular}{|l|c|}
\hline Amino Acid & Value $(\mathrm{g} / 100 \mathrm{~g})$ \\
\hline & \\
Trytophan & 1.27 \\
Lysine & 0.32 \\
Histidine & 1.19 \\
Arginine & 0.35 \\
Aspartic acid & 11.22 \\
\hline
\end{tabular}




\begin{tabular}{|l|c|}
\hline Threonine & 15.36 \\
Serine & 8.24 \\
Glumatic acid & $\mathbf{3 4 . 2 0}$ \\
Proline & 3.52 \\
Glycine & 0.47 \\
Alanine & 2.56 \\
Valine & 2.11 \\
Methionine & - \\
Isoleucine & 0.38 \\
Leucine & 0.48 \\
Tryrosine & 0.31 \\
Phenylalanine & 0.78 \\
\hline
\end{tabular}

Table 3. Vitamin content of freshly-gathered coconut sap (Kozaki, 1974 in Magat, 1996)

\begin{tabular}{|l|c|}
\hline Vitamin & Value $(\mathrm{mg} / \mathrm{dl})$ \\
\hline & 77.00 \\
Thiamine & 12.20 \\
Riboflavin & 38.40 \\
Pyridoxine & 47.10 \\
Paraamonobenzoic acid & 38.40 \\
Pyridoxal & 5.20 \\
Panthothenic acid & 40.60 \\
Nicotinic and & 0.17 \\
Biotin & 0.24 \\
Folic acid & $\mathbf{1 2 7 . 7 0}$ \\
Inositol & 9.00 \\
Choline & trace \\
Vitamin $\mathrm{B}_{12}$ & \\
\hline
\end{tabular}

Table 4. Chemical analysis results (nutrition facts) of coconut sap juice and cocosap concentrate analyzed by Department of Science and Technology (DOST)-XI, Testing \& Calibration Center, Davao City, April 24, 2007.

\begin{tabular}{|l|c|c|}
\hline Parameter & $\begin{array}{c}\text { Coconut sap } \\
\text { juice }\end{array}$ & $\begin{array}{c}\text { Coconut sap } \\
\text { concentrate }\end{array}$ \\
\hline \% Moisture & & \\
\% Ash $^{\mathrm{b}}$ & 84.30 & 25.02 \\
\% Crude protein $^{\mathrm{c}}$ & 0.35 & 1.62 \\
\% Crude fat $^{\mathrm{d}}$ & 0.24 & 0.94 \\
Sodium $^{\mathrm{e}}$ & 0.00 & 0.01 \\
Calcium $^{\mathrm{e}}$ & $18.99 \mathrm{mg} / 100 \mathrm{~g}$ & $63.79 \mathrm{mg} / 100 \mathrm{~g}$ \\
Iron $^{\mathrm{e}}$ & $0.85 \mathrm{mg} / 100 \mathrm{~g}$ & $1.51 \mathrm{mg} / 100 \mathrm{~g}$ \\
\hline
\end{tabular}
\begin{tabular}{|l|l|l|}
\hline & & \\
\hline
\end{tabular}
Methodology Used:
a Moisture Analysis by Air Oven Method (CH-TM- 004)
b Ash Analysis by Gravimetric Method (CH-TM- 001)
${ }^{\mathrm{c}}$ Crude Protein by Kjedahl Method (CH-TM-002)
d Crude Fat by Roese Gottlieb Method, AOAC Official Methods of Analysis, $16^{\text {th }}$ Ed., 1997.
e Atomic Absorption Spectroscopy: Analytical Method (CH-EX-001)
a component of phospholipids in the brain, skeletal, heart and male reproductive tissues (Trinidad, 2000). It functions in nerve transmission, the regulation of enzyme activity and transportation of fats within the body. It is also essential for hair growth and prevent some cases of thinning hair and baldness. It also helps reduce high cholesterol and is important for the heart. Inositol is also beneficial for the treatment of eye abnormalities, eczema and some cases of obesity.

The coconut sap juice, pasteurized healthy drink and coconut sap concentrate, a thick, freeflowing syrup with characteristic coconut sap flavor samples produced by the SMT were analyzed by the Department of Science and Technology (DOST XI) Testing and Calibration Center for their chemical analysis (nutrition facts). Table 4 shows the results of the analysis for coconut sap juice and coconut sap concentrate.

It can be noted that the coconut sap juice and concentrate food products have a moisture content of $84.3 \%$ and $25.0 \%$, respectively. They contain protein and some amounts of micronutrients i.e. calcium $(\mathrm{Ca})$, iron $(\mathrm{Fe})$ and sodium (Na) -Table 5. These micronutrients play vital role in maintaining one's good health (Secretaria, etal., 2006). Calcium is vital for strong bones and teeth, also needed for heart and nervous system and for muscle growth and contraction. While iron is vital for healthy blood, iron deficiency is associated with poor mental development and problem with immune system. While sodium is required by all cells in the body to maintain a normal fluid balance. It also plays a key role in normal nerve and 
muscle (http://www.merck.com/mmhe/sect 12/ch155/ch $155 \mathrm{k} \cdot \mathrm{html})$.

These chemical analyses (nutrition facts) were used in the development of product labels for the two coconut sap products as data on the nutrition facts is one of the information required by DOST for product label development.

The physical (color) analysis of cocosap products, done by the Bureau of Food and Drugs (BFAD) Satellite Laboratory for Mindanao at the Energy Park, Apokon, Tagum City indicated whether the food product has food coloring or none. Since the two products are pure and natural (without any additive), BFAD suggested that only the coconut sap concentrate can be subjected to color analysis. The result showed that no food coloring was detected on the cocosap concentrate confirming that the product is pure and natural, similarly with the coconut sap juice. The pure coconut sap has natural color of cloudy or oysterwhite while the pure coconut concentrate has natural color of golden orange (Fig.7).

\section{Conduct of Food Safety Seminar}

Since the target of the project is to commercialize or market coconut sap juice and concentrate and eventually register the products to the Bureau of Food and Drugs (BFAD), the Project Leader decided to conduct a Food Safety Seminar through the assistance of the Food Safety Team of the Department of Science and Technology, Regional Office XI. The main purpose of this Food Safety Seminar was to provide awareness to the members of the SMT about food hazards (biological, chemical, allergens and physical sources) and how these hazards can be prevented. Also, as the project involves processing of coconut sap food products, the Good Manufacturing Practices (GMP) required by the Dept. of Health-Bureau of Foods and Drugs (DOH-BFAD) was also emphasized to the SMT officers/members.

Thus, a two-day Food Safety Seminar was conducted on April 11-12, 2007 at the Conference Room of the San Roque Store, Tawan-tawan, Baguo District, Davao City. Twenty-four (24) participants consisting of 20 SMT members and 4 employees of PCA-DRC attended the seminar.

Table 5. Partial budget for determining the profitability of producing fermented toddy vs. coconut sap juice and coconut sap concentrate, Barangay Tawan-tawan, Baguio District, Davao City, Philippines

A. Fermented toddy vs. coconut sap juice

\begin{tabular}{|c|c|c|c|}
\hline \multicolumn{2}{|l|}{ TOTAL GAINS } & \multicolumn{2}{|l|}{ TOTAL LOSSES* } \\
\hline Added Returns & Php & Added cost & Php \\
\hline Gross Income & $1,740.00$ & Added cost & $1,082.40$ \\
\hline $\begin{array}{l}\text { Reduced Cost: } \\
\text { None }\end{array}$ & 0 & $\begin{array}{l}\text { Reduced Returns: } \\
\text { None }\end{array}$ & 0 \\
\hline Total A & $1,740.00$ & Total B & $1,082.40$ \\
\hline
\end{tabular}

B. Fermented toddy vs. Coconut sap concentrate

\begin{tabular}{|lc|lc|}
\hline TOTAL GAINS & TOTAL LOSSES & \\
Added Returns & Php & Added cost & Php \\
Gross Income & $1,380.00$ & Added cost & 666.66 \\
\hline
\end{tabular}




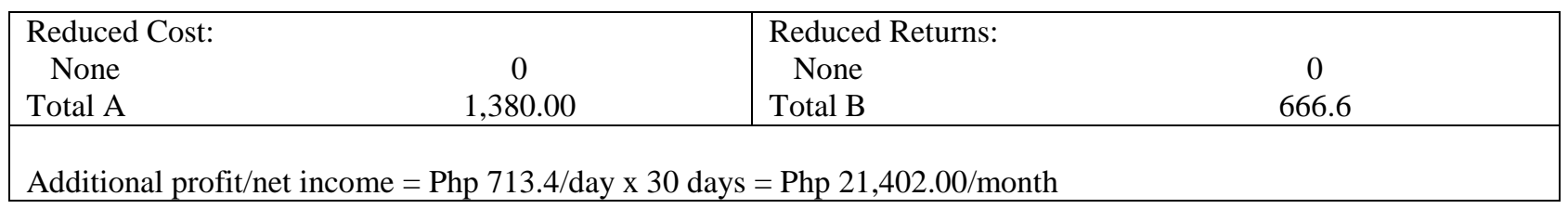

*Details of Cost of Production per day:

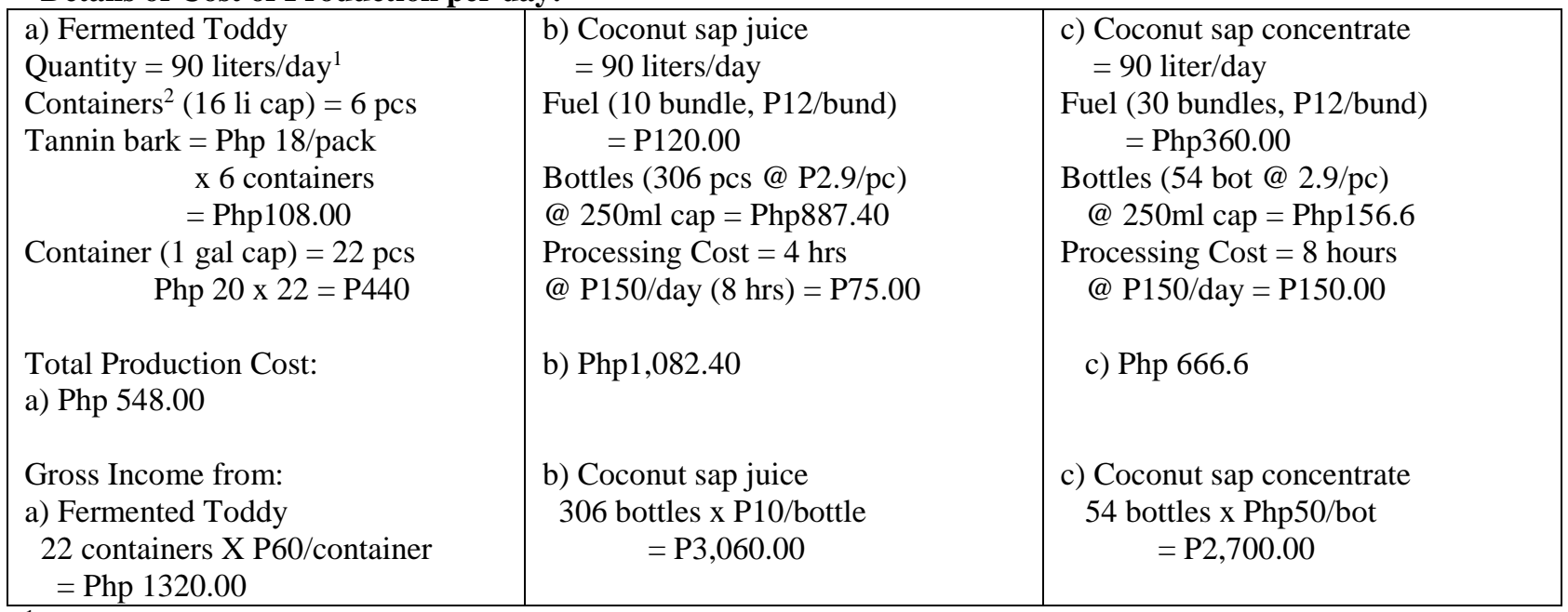

${ }^{1}$ Full tapping of coconut trees with 3 li sap production/day, one tapper can tap 30 trees/day; 90 li/day

${ }^{2}$ Each container requires 1 pack of tannin bark to produce fermented toddy

Non-pecuniary factors:

a) Requires skilled tappers to gather coconut sap daily

b) Provides natural and nutritious foot products

Figure 5. M. Secretaria conducted the actual processing of coconut sap juice and concentrate to SMT members at Tawan-tawan, Baguio District, Davao City.
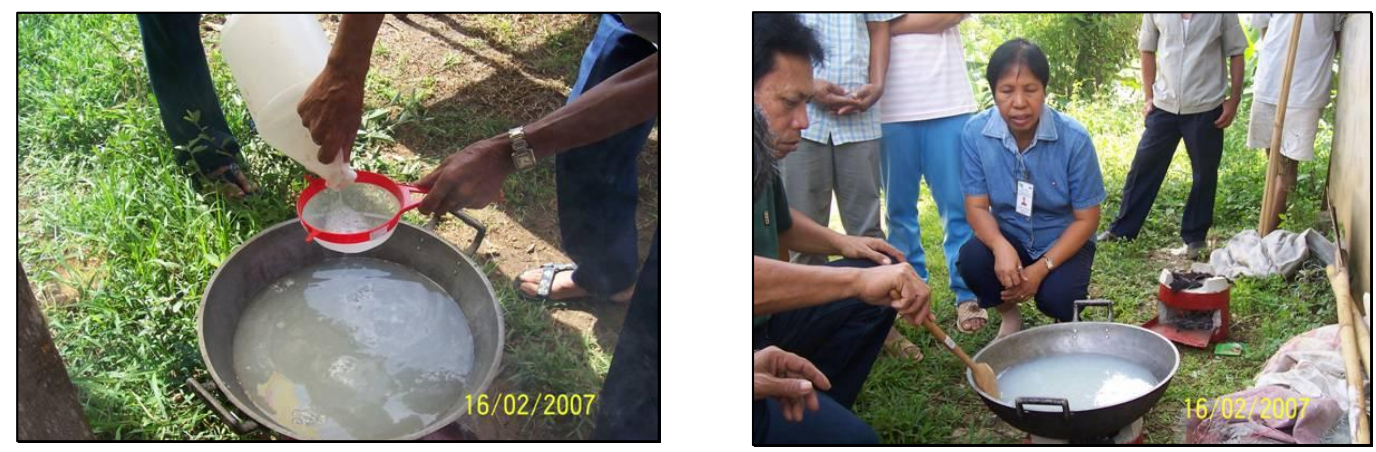

Figure 6. The finished products (cocosap juice and concentrate) were offered to children for taste testing after the actual processing of the products.

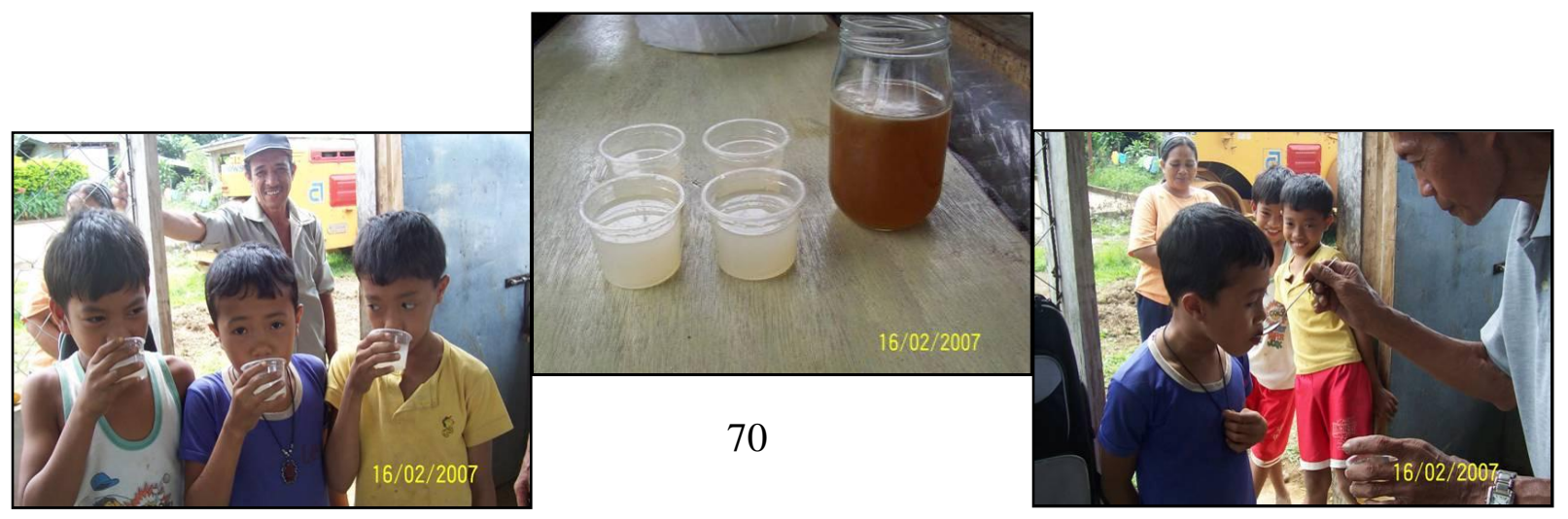


Figure 7. a) Some finished products of cocosap juice (in white plastic containers) and cocosap concentrate (in bottles) were stored in the refrigerator b) Chilled cocosap juice with oyster white color and sap concentrate with golden orange color produced by the Samahang Magniniyugan ng Tawan-tawan.

The Food Safe composed of 4 mem

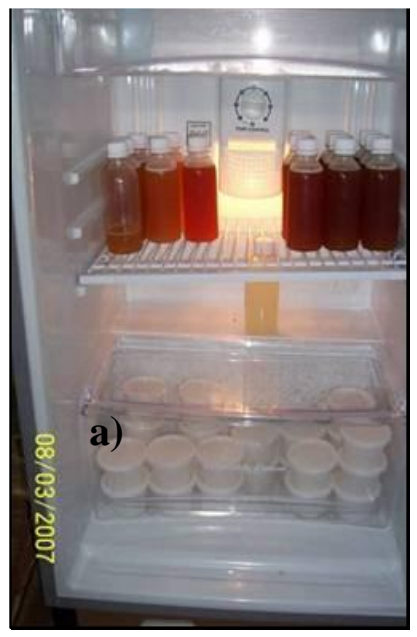

Coordinator, Cecille A. Monton, Alma Lamparas from DOST XI and Aivey P. Oren from SAGREX Food.Corp. as members. The seminar proper consisted of lectures using powerpoint presentation, exercises and actual activity and reporting of exercises done by the participants (Fig. 8). The topics covered during the seminar were as follows:

1) Introduction to food safety

2) Hand washing

3) Personal hygiene

4) Food safety hazards

5) Food contact surfaces

6) Food preparation

7) Cross contamination

8) Pest control

A visit to the proposed processing area (small building owned by SMT) was conducted by the Food Safety Team, SMT Officers and Project Leader to evaluate the status of the area for improvement so that processing of coconut sap juice and concentrate can be done in this area.

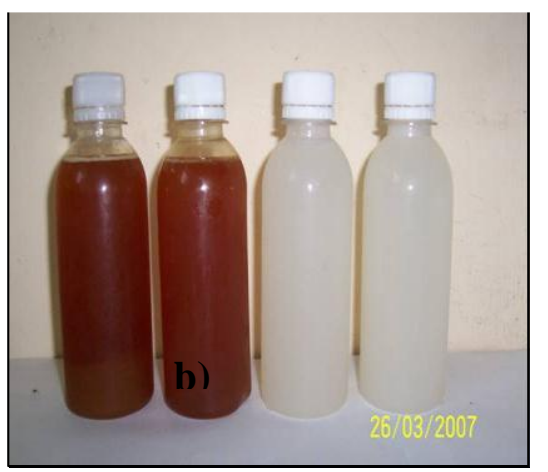

The processing of coconut sap products, mainly coconut sap concentrate was done in the cooking facility of one of the SMT officers due to lack of proper processing area. Thus, the Food Safety Team recommended for the renovation of the processing area considering some vital requirements of BFAD on the design of plant and plant facilities. In this connection, Mr. Adon, Sr., SMT Chairman recommended to the SMT Board of Directors for the renovation of existing SMT building so that full implementation of the production and commercialization of coconut sap juice and concentrate can be implemented. Likewise, water and electric connection in this area was recommended for immediate installation.

A draft of the proposed processing area was prepared by the SMT Chairman as a guide to the construction of this facility. With additional funding from possible government/non-government agencies and the SMT's funding, it is hoped that the renovation of this building will be done soonest in time for the processing of cocosap juice/concentrate for the opening of school classes at Tawan-tawan (target buyers of the products). 
As a result of the seminar, it was decided by the SMT Officers that production of cocosap concentrate will be stopped temporarily on April 12, 2007 while awaiting the product labels and renovation of the processing plant/area. As of April 11, 2007, a total of 283 bottles (@ $250 \mathrm{ml}$ capacity) of coconut concentrate were produced for disposal. While awaiting for label of the product, most of the products were sold at trade fair/exhibits at Davao City and other provinces in Region XI thru the assistance of PCA-Davao Research Center.

\section{Promotion of coconut sap food products via trade exhibits and lecture series}

During a short period from Feb. 25 to April 11, 2007, a total of 283 bottles of coconut sap concentrate was produced by the Samahang Magniniyugan ng Tawan-tawan. To promote the sale of this product (without label yet), these were brought by the Project Leader to PCA-DRC and were displayed / sold at the Kabisig Trade
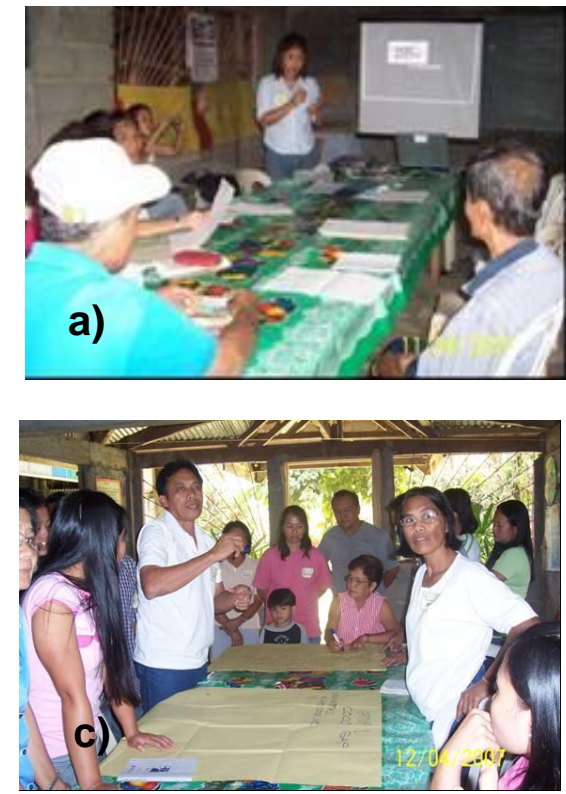

Fair held at the Sangguniang Panglungsod ng Davao, Davao City last March 20-23, 2007 (Fig. 9) and in Cateel, Davao Oriental during the launching of PCA-DAR/MINSAAD Project on March 29-30, 2007 and to visitors (students, coconut farmers and stakeholders) of PCADRC. During these occasions, information, education and communication (IEC) materials such techno guide sheet on the production of natural and nutritious coconut sap food products (PCA Technology Guide Sheet 16, series of 2006) were distributed to visitors and interested parties.

Figure 8. Some of the activities during the Foc April 11-12, 2007: a) lectures using p hand washing exercise c) process flow workshop output by the participants.
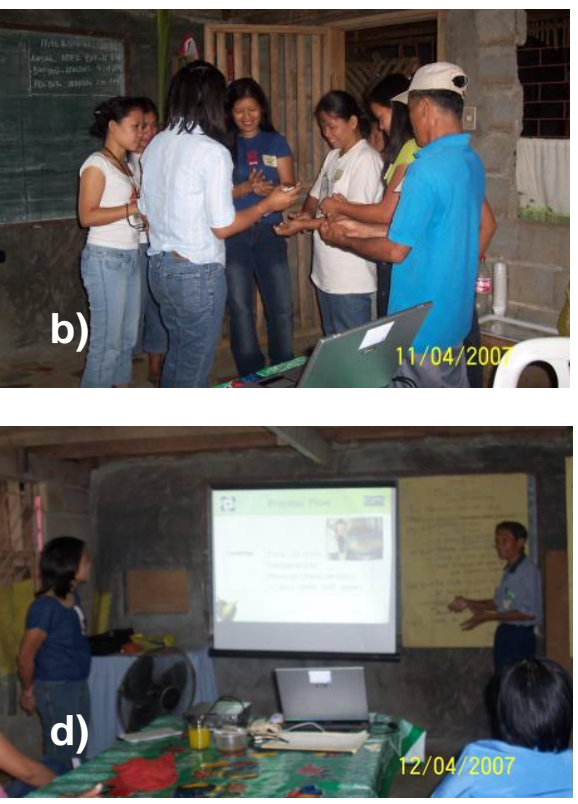

Figure 9. Some frozen coconut sap juice and cocosap concentrate produced by SMT were displayed and sold at the Kabisig Trade Exhibit at a the Sangguniang Panglungsod ng Davao on March 20-23, 2007 at a1 Davao City, Philippines.

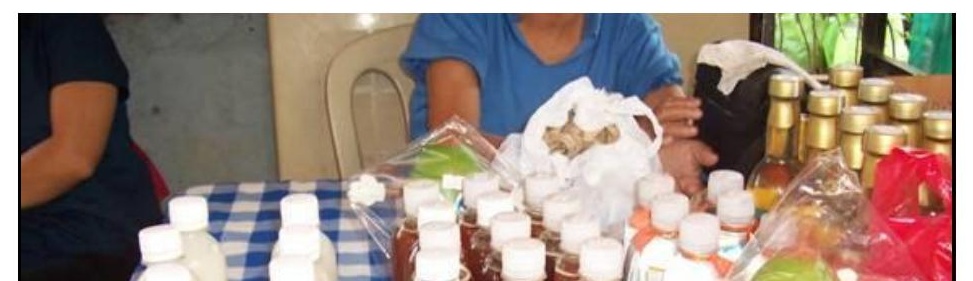


Likewise, an awareness lecture forum was done by the Project Leader at Baguio High School of Agriculture (BHSA) on March 28, 2007 at the graduation rites of the Kalikasan Season-long Farmers' Field School at Tawantawan, Baguio District with fourth year high school students and Malagos farmers as participants. During this short forum, samples of coconut sap juice were distributed and sold to BHSA School Principal and teachers and students, Baguio Local government Officials and farmers. Mr. Wilfredo C. Dalogdog, School Principal of Baguio High School of Agriculture even invited the Project Leader for a lecture/talk about the beneficial effects (social, economic and health) of coconut sap food products to the general assembly of the Parents and Teachers Association (PTA) of BHSA on June, 2007, start of the school opening.

As the technology on coconut sap food products is being promoted at the regional level (thru PCA-Regional/Provincial Offices XI, DABAR Regional Techno Commercialization Forum and at national level (during the PCA National Coco Week Celebration-Trade Fair \& Exhibits at the SM Mega Mall on the last week of August 2006 and 2007), several PCA units such as the PCA-Zamboanga Research Center, San Ramon, Zamboanga City; PCA-New Coconut Seed Production Center, Carmen, Aroman, North Cotabato are now producing coconut sugar and concentrate from about 300 trees (more or less 3 has of coconut trees); PCA-Davao Research
Center at Bago Oshiro, Davao City (50 trees $1 / 2$ ha) for coconut sap juice and concentrate; private business enterprise such as the Sorsogon Food Enterprise of Sorsogon, Sorsogon, Bicol Region, with 120 coconut trees (more than one ha) being tapped for the commercial production of cocosap juice and concentrate; Lao Integrated Farm of Bansalan, Davao del Sur, Southern Mindanao with 50 trees being tapped for the production of coconut sugar and sap drink/juice and Linabu Small Coconut Planters Association of Balingasag, Misamis Oriental, Northern Mindanao with more or less one ha of coconut trees for the production of cocosap sugar.

Several coconut farmers' organizations and Local Government Unit (LGU) in different coconut-growing areas i.e. coconut farmers from GASA Foundation, Tandag, Surigao del Sur; LGU-Surigao del Sur; LGU-Barangay Pansabungan, Mandaue, Cebu; LGU-Barangay Tacunan, Davao City; LGU-Davao del Norte; Farmers Field School (FFS) in Maduao, Panabo, Tagum City; FFS in Nabunturan, Compostela Valley; coconut farmers/recipients of Josefa Segovia Foundation, Calinan, Davao City have already visited and consulted the Technology Generator (M.I. Secretaria), at PCA-DRC, Bago Oshiro, Davao City for possible adoption and commercial production of these cocosap food products in their localities. Some of them have been trained by the Technology Generator on the cocosap food processing. From the technology briefing/training done by the 
Technology Generator, they expect that this technology can be a good source of livelihood project for their respective coconut farming communities.

\section{Product labeling of coconut sap juice and coconut sap concentrate}

As part of the product development and commercialization of these products, product labels for coconut sap juice and concentrate was made through the assistance of DOST XI artist. The product labels (to be placed in the containers of cocosap juice and cocosap concentrate) consisted of the nutrition facts, definition of coconut sap, main ingredient, producer/manufacturer of the products, capacity content of the container and other relevant information (Fig. 10). The brand name of these two coconut sap food products were "SMT Coconut Sap Juice" and "SMT Coconut Sap Concentrate" since the manufacturer or producer is the Samahang Magniniyugan ng Tawan-tawan (Fig.11). The product labels were mass produced for labeling

Figure 10. The coconut sap juice and concentrate labels developed by DOST Artist, April 2007.
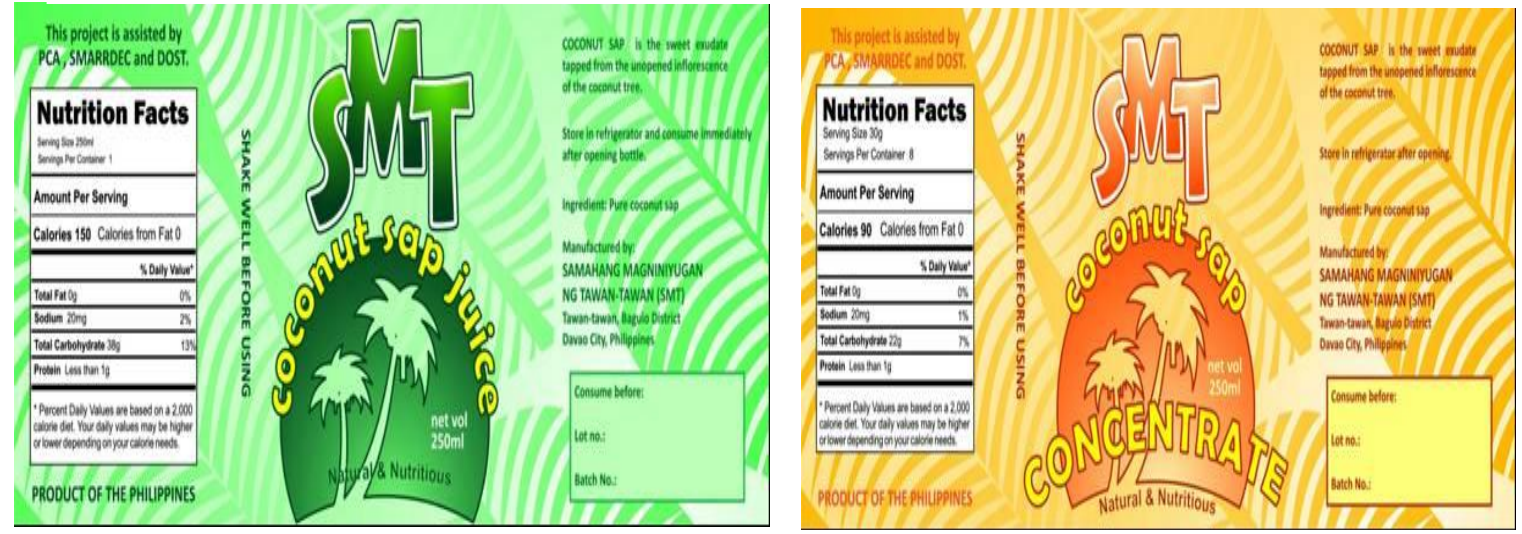

Figure 11. The coconut sap juice and coconut sap concentrate produced by the Samahang Mangniniyugan ng Tawan-tawan with the product labels ready for marketing, May 2007.

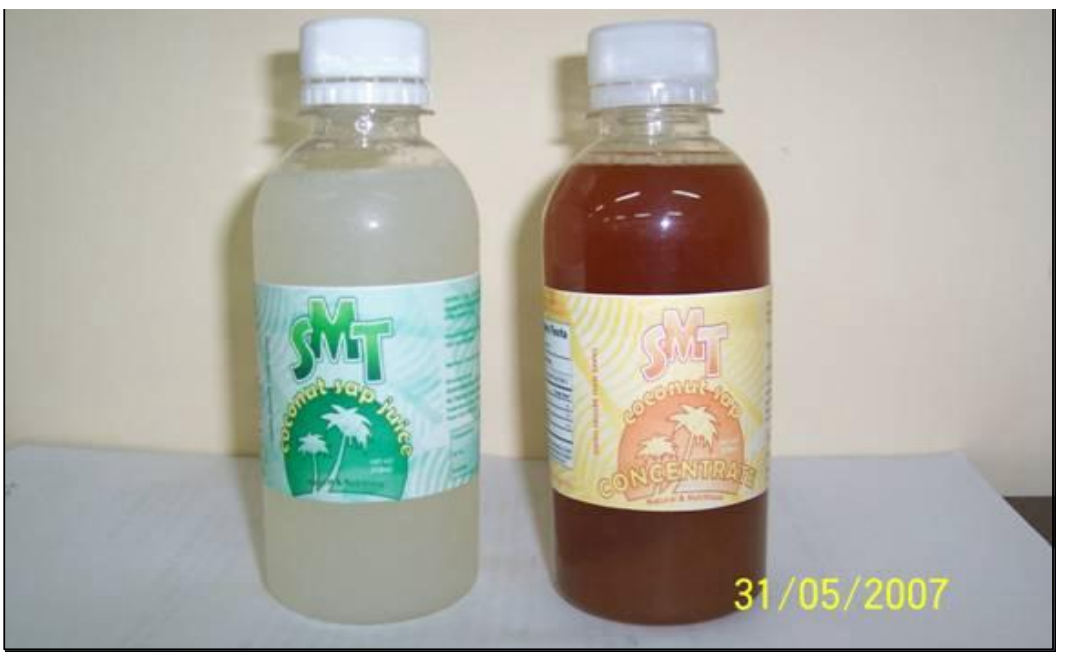


of the two cocosap food products for marketing/commercialization purposes.

\section{Economic Analysis on the Production of Cocosap Juice and Cocosap Concentrate}

The partial budgeting, a relatively simple profitability tool that is used to analyze the costs and return of business decision that affect only a small part of the farm operation was used to evaluate the profitability of the new technology (Aragon, 2002). Analysis and computations were held to a minimum with partial budgeting since only the costs and returns that change as a result of adjustment in one segment of the farm business were considered.

The new proposed technology i.e. production of coconut sap juice and concentrate was tested for profitability against the traditional technology on the production of coconut fermented toddy 'tuba' (commonly practiced by the coconut farmers in the locality).

Based on 30 trees per month production of coconut sap with full tapping, 90 liters of coconut sap/month assuming three (3) liters pf coconut sap were produced daily by a tapper. Table 5 which shows that partial budgeting for determining the profitability of new product (cocosap juice) over the fermented toddy indicated a monthly additional profit/net income of P19,728.00. While the monthly additional profit/net income of producing coconut sap concentrate over fermented toddy was Php $21,402.00(\mathrm{P} 41=1 \$)$. These results indicated that the new proposed technology of producing coconut sap juice and concentrate was more profitable than the present situation, i.e producing fermented toddy.
Based on the data obtained by actual processing of coconut products by cooperatives and family business in the Philippines, the economic return analysis at village-level was made in the manner that the same number of coconut was used in the processing of the different products for comparison purposes (Sanchez, 1993). Furthermore, the assumption in the calculation of the cost of production is that the facilities and equipment are existing.

The cost and return analysis of the different products produced from the same number of nuts (4368 pcs.) showed that the net income (US\$ 3211.24) obtained from nata de coco was the highest (Sanchez, in www.ipgri.cgiar.org/publications). This is followed by processing nuts into coco-filled white soft cheese (US\$ 1360.58), coco yoghurt (US\$ 952.64), coco water beverage (US\$ 411.62), coco brittle (US\$336.87), coco water vinegar (US\$ 314.44) and coco jam (US\$ 252.21).

\section{Conclusion and Recommendation}

The processing of natural and nutritious coconut sap juice and concentrate for commercial production was done by a small coconut farmers' organization (SCFO) i.e the Samahang Magniniyugan ng Tawan-tawan (SMT) at Barangay Tawan-tawan, Baguio District, Davao City. This technology was adopted by the members of the SMT through the technical assistance of the Technology Generator (Project Proponent) from PCA-Davao Research Center, Bago Oshiro, Davao City. 
The adoption of this technology provided several benefits to the SMT and the local community of Tawan-tawan. It provided employment to coconut farmers/coconut tappers who produce the coconut sap and womenmembers who process the cocosap food products; gave nutritious/healthy beverage to young people (students) and adults (rural folks), and snack food for all types of people and provided for extra farm income to this coconut farming community of Davao City.

The development of the technology on natural and nutritious food products from coconut sap is very timely considering the growing consciousness of consumers on safe, organic and healthy food products. It provides additional job opportunities among coco-based farming communities, where members of the family particularly women could be involved in the food processing of valuable and healthy products. Another consideration is that technologies are simple, non-expensive and easy-to-apply procedures. Likewise, this product diversification scheme can promote multi-uses and competitiveness of the coconut palm.

As this technology proved to be feasible and profitable in this part of the country, (Davao City, Philippines), it is also highly recommended to coconut farming communities in the other parts of the country where local full bearing coconut hybrids are planted and can be tapped for increased total coconut farm productivity.

Some of the factors to consider for a successful commercialization/marketing of cocosap juice and concentrate are recommended: 1) skilled labor for sap production (toddy tapping); 2) suitable environment and available full bearing coconut palms [preferably local hybrids]; 3) technical know how on the processing of cocosap food products; 4) ready market for cocosap products; and 5) adequate initial operating capital.

\section{Acknowledgement}

The authors wish to express their sincere gratitude to the 1) Management of the Philippine Council for Agriculture, Forestry and Natural Resources Research and Development (PCARRD) through the Southern Mindanao Agriculture and Resources Research and Development Consortium (SMARRDEC) headed by Dr. Lourdes C. Generalao, Consortium Director for the financial support for this technology commercialization/ promotion project; 2) Mr. Lornito U. Orillaneda, PCA-Regional Manager, PCA-Region XI and Officer-in-Charge, PCA-DRC and Ms. Socorro Pueblo, Provincial Manager, PCA-Davao City, for their support in the promotion and dissemination of the technology to prospective clienteles within Region XI (Southern Mindanao); 3) Ms. Marianita N. Eroy, Officerin-Charge of the Agronomy \& Soils Division (ASD), PCA-DRC for her utmost support during the implementation of the project; and 4) ASD support personnel and Regional Office technical staff for their untiring assistance in the promotion of the coconut sap food products in various occasions in Region XI.

\section{References}

Aragon, C.T. 2002. The use of partial budgeting in coocnut-based farming systems. Training lecture paper presented during the Workshop on TechnologyDemonstration of PCA matured technologies in Integrated Farming Ssytems Development Sites in Davao City, Region XI held on May 28-30, 2002 at PCA-CETC, Davao City, Philippines.

Cruz. L., M. Vallejos \& J.A. Gamolo. 2006. Coconut Sap Sugar Commercialization: A Success Story. Paper presented during the PCA National .RD In-house Review, PCA-ZRC, San Ramon, Zamboanga City, May 30, 2006. 5 p.

Magat, S.S. 1996. Intercropping and toddy/sugar production in CBFS: Possible integration with germplasm conservation and varietal improvement. In: Batugal, 
P., R. Rao and C. Bong (Editors) Proceedings of the Workshop on Promoting Multi-Uses \& Competitiveness of the Coconut. Sept. 26-29, 1996, Chumpon, Thailand.

Maravilla J.N. and S.S. Magat. 1993. Sequential coconut toddy and nut production scheme in 'Laguna' tall variety and hybrid coconuts. The Phil. Journal of Coconut Studies. 18 (2):7-15.

Naka, P. 1996. Potential of producing sugar from coconut and requirement for varietal development. In: Batugal, P., R. Rao and C. Bong (Editors) Proceedings of the Workshop on Promoting Multi-Uses \& Competitiveness of the Coconut. Sept. 2629, 1996, Chumpon, Thailand.

Sanchez, P.C. 1993. Challenges and Opportunities in Commercial Production and Marketing of Non-traditional Coconut Food Products and By-products. Asian and Pacific Coconut Community Publication, Jakarta, Indonesia. pp. 147-266.

Secretaria, M.I., R.M. Ebuna and S.S. Magat. 2006. Production of natural and nutritious coconut sugar, juice, honey and vinegar from coconut sap. Paper presented during the First Regional Technology Commercialization Forum. Aug. 17, 2006. Davao Convention Center, Davao City.

Secretaria, M.I., R.M. Ebuna and S.S. Magat. 2006. Techno Guide Sheet No. 16. Natural and nutritious sugar, honey, juice and vinegar from coconut sap. Series of 2006. Produced by Crop Agronomy, Nutrition and Farming Systems (CANFARMS) Program, PCA-Research, Development \& Extension Branch, Diliman, Quezon City

Secretaria, M.I., R.M. Ebuna and S.S. Magat. 2003. Techno Guide Sheet No. 8. Series of 2003. Revised 2006. Producing high value "organic and green" foods from coconut sap at village level. Produced by Crop Agronomy, Nutrition and Farming Systems (CANFARMS) Program, PCAResearch, Development \& Extension Branch, Diliman, Quezon City.

Secretaria, M.I., R. Ebuna \& S.S. Magat. 2003. On-farm production and processing of selected coconut sap-based natural and nutritious food products from SCTNP scheme. Coconut Research and Development (CORD) Journal, XIX (2):20-31. Published by the Asian and Pacific Coconut Community (APCC), Jakarta, Indonesia.

Secretaria, M.I., R.M. Ebuna and S.S. Magat. 2002. Performance of selected coconut varieties/hybrids under the sequential coconut toddy and nut production (SCTNP) scheme. Coconut Research \& Development (CORD) Journal. XVIII (1) 12-28. Published by the Asian Pacific Coconut Community, Indonesia, Jakarta.

Secretaria, M.I., R.M. Ebuna, R.M. Madrazo, S.S. Magat, J.N. Maravilla, G. Santos and G. Baylon. 1997. Sequential coconut toddy-nut production scheme in different coconut cultivars and hybrids: Production, processing and marketing of products. (NEDA/TRP Proj. No.97-0130-229) Final Report. PCA-Zamboanga Research Center San Ramon Zamboanga City. Sept. 30,1997. 56 p.

Trinidad, T. P. 2000. Potential of coconut sapbased sugar as high value organic food. Selected topics on coconut trends and prospects in enhancing the coconut industry. Coconut Week 2000 Symposium Proceedings. PCA, Quezon City. 92 p. 